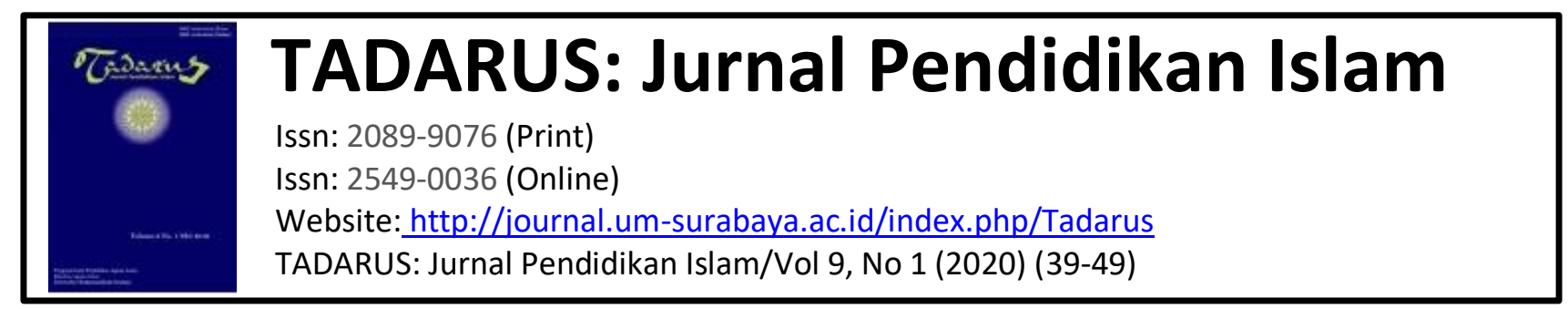

\title{
PENERAPAN NILAI-NILAI KARAKTER DALAM NOVEL NEGERI 5 MENARA PADA SISWA KELAS XII USAHA PERJALANAN WISATA 2 DI SMK SATYA WIDYA SURABAYA
}

\author{
${ }^{1}$ Anggrayu Kurnia Saputri, ${ }^{2}$ Mukhammad Bakhruddin \\ ${ }^{1}$ Anggrayu_kurnia@gmail.com, ${ }^{2}$ bahrudin@fai.um-surabaya.ac.id \\ Program Studi Pendidikan Agama Islam, Universitas Muhammadiyah Surabaya
}

\begin{abstract}
Abstrak
Penerapan Nilai-nilai Karakter Dalam Novel Negeri 5 Menara Pada Siswa Kelas XII Usaha Perjalanan Wisata 2 di SMK Satya Widya Surabaya. Masalah yang dibahas dalam penelitian ini adalah nilai-nilai karakter yang terkandung dalam novel Negeri 5 Menara, penerapan nilai-nilai karakter dalam novel Negeri 5 Menara pada siswa kelas XII Usaha Perjalanan Wisata 2 di SMK Satya Widya Surabaya, dan faktor-faktor penghambat dan penunjang dalam penerapan nilai-nilai karakter dalam novel Negeri 5 Menara pada siswa kelas XII Usaha Perjalanan Wisata 2 di SMK Satya Widya Surabaya.
\end{abstract}

Kata Kunci: Nilai Karakter, Novel Negeri 5 Menara

\section{Pendahuluan}

Persoalan yang terjadi pada masyarakat tentang perilaku anak - anak sekarang, dirasa semakin meresahkan dan melanggar dari norma agama, kaidah - kaidah nilai kesopanan atau tata karma dan nilai-nilai keagamaan yang terjadi di kalangan pelajar ataupun mahasiswa dan kalangan lainnya jelas menunjukkan kerapuhan karakter yang cukup parah yang salah satunya lembaga pendidikan. Dalam pelaksanaan pendidikan karakter tidaklah hanya diserahkan kepada guru agama saja, karena dalam pelaksanaan pendidikan harus dipikul oleh semua pihak, temasuk kepala sekolah, para guru, staf tata usaha, tukang sapu, penjaga kantin, dan bahkan orang tua di rumah. Untuk mewujudkan siswa yang berkarakter, diperlukan upaya yang tepat melalui pendidikan. Karena pendidikan mempunyai peranan penting dan dalam menanamkan, menerapkan karakter positif siswa, serta mengubah karakter anak didik yang tidak baik akan berubah menjadi lebih baik.

Berdasarkan fakta di atas, dalam penelitian ini akan dibahas tentang nilai karakter yang bisa diambil dari Novel Negeri 5 Menara untuk diterapkan terhadap 
siswa di SMK Satya Widya Surabaya Di dalam novel Negeri 5 Menara, Oleh karena itu penulis tertarik untuk mengkaji novel Negeri 5 Menara karya A. Fuadi dan membuat karya ilmiah yang berjudul tentang Penerapan Nilai-nilai Karakter dalam Novel Negeri 5 Menara pada siswa kelas XII Usaha Perjalanan Wisata 2 di SMK Satya Widya Surabaya.

\section{Landasan Teori}

1. Konsep Nilai

a. Pengertian Nilai

Nilai berasal dari bahasa Latin vale're yang artinya berguna, mampu akan, berdaya, berlaku, sehingga nilai diartikan sebagai sesuatu yang dipandang baik, bermanfaat dan paling benar menurut keyakinan sesorang atau sekelompok orang. Nilai adalah kualitas suatu hal itu disukai, diinginkan, dikejar, dihargai, berguna dan dapat membuat orang yang menghayatinya menjadi bermartabat. ${ }^{1}$

b. Nilai-nilai Pembentuk Karakter

Ada 18 nilai pembentuk karakter yang mana nilai karakter ini harus diterapkan oleh lembaga terutama sekolah. yaitu : 1) Religius; 2) Jujur; 3) 3) Toleransi; 4) Disiplin; 5) Kerja Keras; 6) Kreatif; 7) Mandiri; 8) Demokratis; 9) Rasa Ingin Tahu; 10) Semangat Kebangsaan; 11) Cinta Tanah Air; 12) Menghargai Prestasi; 13) Bersahabat/Komunikatif; 14) Cinta Damai; 15) Gemar Membaca; 16) Peduli Lingkungan; 17) Peduli Sosial; dan 18) Tanggung Jawab.

c. Indikator Nilai Karakter

Ada 2 (dua) jenis indikator yang dikembangkan dalam hal ini. Pertama adalah indikator untuk sekolah dan kelas. Kedua adalah indikator untuk mata pelajaran. Indikator sekolah dan kelas adalah penanda yang digunakan oleh kepala sekolah, guru dan personalia sekolah dalam merencanakan, melaksanakan, dan mengevaluasi sekolah sebagai lembaga pelaksana pendidikan budaya dan karakter bangsa. Indikator mata pelajaran menggambarkan perilaku afektif seorang peserta didik berkenaan dengan mata pelajaran tertentu.

2. Karakter

Secara etimologi, istilah karakter berasal dari bahasa Latin character, yang antara berarti watak, tabiat, sifat-sifat kejiwaan, budi pekerti, kepribadian dan akhlak.

1 Sutarjo Adisusilo, Pembelajaran Nilai Karakter (Konstruktivisme dan VCT Sebagai Inovasi Pendekatan Pembelajaran Afektif), (Jakarta: Raja Gafindo Persada, 2012), 56. 
Istilah karakter juga diadopsi dari bahasa Latin kharakter, kharessian, dan xharaz yang berarti tool for making to engrave, dan pointed stake. ${ }^{2}$ Secara terminologi (istilah), karakter diartikan sebagai sifat manusia pada umumnya yang bergantung pada faktor kehidupannya sendiri. Karakter adalah sifat kejiwaan, akhlak, atau budi pekerti yang menjadi ciri khas seseorang atau sekelompok orang.

\section{Konsep Novel}

Novel adalah kisah dari seorang penulis tentang apa yang terjadi dalam dirinya maupun lingkungan sekitarnya sehingga dari kisah - kisah itu penulis novel akan mengembangkan sebuah cerita dari apa yang ia pikirkan atau alami langsung. Biasanya cerita yang dikisahkan oleh seorang penulis novel mempunyai karakteristik atau watak tersendiri dalam setiap pelaku yang diceritakan didalamnya. Dan setiap novel pasti mempunyai nilai-nilai tersendiri, baik itu nilai moral, nilai pendidikan dan lain-lain. Yang akan dijabarkan disini adalah tentang unsur Intristik Novel yaitu unsur yang membangun karya sastra dari dalam. Diantaranya sebagai berikut : Tema, Alur/Plot, Tokoh dan Penokohan, Latar, Amanat.

\section{Penerapan Nilai Karakter}

Wadah yang paling strategis dan efektif untuk mewujudkan pendidikan karakter tersebut adalah dunia pendidikan sejak dari PAUD hingga Perguruan Tinggi. Sebagai wadah paling strategis satuan pendidikan dapat melakukan pembinaan dan pengembangan karakter dengan menggunakan : Pendekatan terintegrasi dalam semua mata pelajaran, Pengembangan budaya satuan pendidikan, Pelaksanaan kegiatan kokurikuler dan ekstrakurikuler, Pembiasaan perilaku dalam kehidupan di lingkungan satuan pendidikan. Pembangunan karakter melalui satuan pendidikan dilakukan mulai dari pendidikan usia dini sampai pendidikan tinggi. Salah satu kunci keberhasilan program pengembangan karakter pada satuan pendidikan adalah keteladanan dari para pendidik dan tenaga kependidikan. Keteladanan bukan sekedar sebagai contoh bagi peserta didik, melainkan juga sebagai penguat moral bagi peserta didik dalam bersikap dan berperilaku.

\section{Metode Penelitian}

Metode yang digunakan dalam penelitian ini adalah Penelitian Kualitatif. Penelitian ini meneliti nilai-nilai karakter yang ada dalam novel Negeri 5 Menara,

\footnotetext{
2 Musfah, Pendidikan Karakter:Sebuah Tawaran Model Pendidikan Holistik-Integralistik (Jakarta: Prenada Media,2011), 127.
} 
penelitian yang menggunakan metode analisis isi (data) yang mana dalam metode ini adalah pembahasan mendalam terhadap isi suatu informasi tertulis atau tercetak dalam media massa. Penelitian ini dilakukan di SMK Satya Widya Surabaya. SMK Satya Widya Surabaya adalah lembaga Pendidikan tingkat menengah kejuruan yang berkonsentrasi dalam program Keahlian Usaha Perjalanan Pariwisata dan Usaha Akomodasi Perhotelan. Lembaga ini berdiri sejak tahun 1990 dibawah naungan Yayasan Satya Widya Surabaya, yang terletak di Jl. Menur 2A Surabaya (Karangmenjangan 118). Subjek pada penelitian ini adalah Siswa XII Usaha Perjalanan Wisata 2, dan Objek pada penelitian ini adalah Novel Negeri 5 Menara karya Ahmad Fuadi Cetaka Pertama 2009.

Sumber data primer yang digunakan pada penelitian ini berupa observasi terhadap lokasi penelitian, wawancara dan sumber data tertulis yang terdapat pada novel "Negeri 5 Menara". Data tersebut berupa kata-kata, kalimat, atau wacana yang mengandung nilai-nilai karakter. Novel "Negeri 5 Menara" ini diterbitkan untuk pertama kalinya pada tahun 2009 terdiri dari 46 bab 405 halaman, dan Sumber Data Sekunder diperoleh dari berbagai sumber seperti jurnal, buku, dan artikel yang berhubungan dengan objek penelitian.

Teknik Analisis Data pada penelitian ini yaitu Tahapan pertama yaitu pengumpulan data mengenai novel negeri 5 menara dan pencarian informan. Tahapan kedua yaitu mengidentifikasi dan menganalisis nilai-nilai karakter dalam novel negeri 5 menara dengan menghubungkan data sesuai dengan topik penelitian. Dan tahapan ketiga adalah penarikan kesimpulan yang merupakan tahap paling akhir dalam proses pengolahan data kualitatif

\section{Hasil dan Analisis Penelitian}

1. Hasil Penelitian

a. Biografi Ahmad Fuadi

Ahmad Fuadi lahir di Bayur, kampung kecil di pinggir Danau Maninjau tahun 1972, tidak jauh dari kampung Buya Hamka. Fuadi merantau ke Jawa, mematuhi permintaan ibunya untuk masuk sekolah agama. Negeri 5 Menara adalah buku pertama dari sebuah trilogi. Ditulis oleh Ahmad Fuadi, mantan wartawan TEMPO\&VOA, penerima 8 beasiswa luar negeri, penyuka fotografi, dan terakhir menjadi Direktur Komunikasi di sebuah NGO Konservasi. Alumni Pondok Modern Gontor HI Unpad, George Washington University, dan Royal Holloway, University 
of London ini meniatkan sebagian royalti trilogi ini untuk membangun Komunitas Menara, sebuah lembaga sosial untuk membantu pendidikan orang yang tidak mampu dengan basis sukarelawan.

\section{b. Sinopsis Novel Negeri 5 Menara}

Diceritakan tentang enam orang anak yang menyebut diri mereka sebagai sahibul menara yang mempunyai cita-cita dan impian yang sangat tinggi, yang pada akhirnya mereka mampu mencapai apa yang mereka impi-impikan dengan kerja keras, ketekunan dan disiplin. Cerita ini dilatarbelakangi oleh kehidupan pesantren yang berhasil menanamkan nilai-nilai karakter pada anak didik sehingga kelak menjadi orang-orang yang berkualitas dan berjiwa ikhlas. Novel "Negeri 5 Menara" ini terinspirasi oleh pengalaman penulis yang menikmati pendidikan yang mencerahkan di Pondok Modern Darussalam Gontor. Yang mana semua tokoh utama dalam novel ini terinspirasi oleh sosok asli, dan beberapa lagi adalah gabungan dari beberapa karakter yang sebenarnya.

c. Unsur Intrinsik Dalam Novel Negeri 5 Menara

1) Tema

Disini tema yang disampaikan pengarang adalah sepotong kata asing bak mantera ajaib yang ampuh bekerja yaitu Man Jadda Wajada. Mantera ajaib berbahasa Arab ini bermakna tegas: "Siapa yang bersungguh-sungguh, akan berhasil." Kata mutiara yang sederhana tapi kuat itu menjadi kompas kehidupan bagi keenam sahibul menara tersebut. Sebagaimana kutipan berikut :

\section{2) Tokoh Sentral}

Alif adalah anak remaja lulusan sekolah negeri SMP yang berasal dari Maninjau, Bukittinggi, Sumatera Barat. ${ }^{3}$ Berkemauan keras dan mempunyai cita-cita tinggi. Dulmajid adalah anak yang sederhana dan pemberani. Raja adalah anak yang berasal dari Medan. Nama lengkapnya adalah Raja Lubis. Raja adalah anak yang rajin, pandai dan gemar membaca. Said yang berasal dari Surabaya ini mempunyai sifat pemimpin, dewasa. Baso adalah anak yang berasal dari Gowa. Baso bersifat baik, cerdas, selalu membantu teman. Atang adalah anak yang berasal dari Bandung, mempunyai sifat mudah bergaul, baik hati, humoris.

\footnotetext{
${ }^{3}$ Ahmad Fuadi, Negeri 5 Menara, (Jakarta: PT. Gramedia Pustaka Utama 2009), 43.
} 


\section{3) Tokoh Periferal}

Amak adalah Ibu Alif. Sifatnya yang baik, memikirkan masa depan anaknya, dan murah senyum. Ayah adalah ayah Alif. Beliau seorang yang tegas dan penyayang. Ayah dalam novel ini juga pendiam dan selalu menyetujui perkataan Amak. Ustad Salman disini sebagai wali kelas Alif. Sifatnya yang royal dan selalu enerjik dalam mengajar. Kiai Rais adalah panutan semua santri selama di Pondok Madani. Dia seorang pendidik dengan pengetahuan dan pengalaman lengkap. ${ }^{4}$ Sifatnya penyabar, murah senyum dan berwibawa. Tyson adalah sebutan dari 6 tokoh dalam novel kepadanya. Tyson yang bernama asli Rajab Sujai adalah Kepala Keamanan Pusat di Pondok Madani. Pemeran Tyson disini keras, tegas dan menyeramkan.

4) Alur

Alur yang diceritakan penulis adalah cerita flashback, yang mana penulis di awal menceritakan dirinya pada lembar pesan di masa silam kalau dirinya berada di Washington DC. Lalu penulis menceritakan masa lalu yang mana penulis bercerita tentang awal dia lulus madrasah dan ingin mendaftar SMA terbaik di Bukittinggi dan akhirnya harapannya pupus karena keinginan Amak yang ingin dia bersekolah di sekolah Agama. Lalu penulis menceritakan kisahnya lagi selama di Pondok Madani hingga bertemu dengan 5 temannya dan di akhir cerita penulis bercerita tentang detikdetik ujian lisan dan tulis dan kelulusan dengan mengikuti puncak acara yudisium dan khutbatul wada' sampai penulis meninggalkan Pondok Madani. Lalu cerita kembali lagi ke penulis yang menyatakan dirinya berada di London dan bertemu dengan 2 temannya Atang dan Raja.

5) Latar

Latar Tempat: tempat Alif di Washington $\mathrm{DC}^{5}$, Rumah Alif di Maninjau Bukittinggi ${ }^{6}$, Pondok Madani, rumah Atang di Bandung, ${ }^{7}$ rumah Said di Surabaya, ${ }^{8}$ Trafalgar Square di London, ${ }^{9}$ Apartement Raja d dekat stadion Wembley. ${ }^{10}$ Latar Waktu: di dalam novel ini penulis lebih banyak bercerita kegiatannya di Pondok Madani. Dan kejadian ini terjadi sekitar tahun 1988-1993 yaitu penulis adalah santri

\footnotetext{
${ }^{4}$ Ahmad Fuadi, Negeri 5 Menara, 49.

${ }^{5}$ Ahmad Fuadi, 1 .

${ }^{6}$ Ahmad Fuadi, 5.

${ }^{7}$ Ahmad Fuadi, 218.

${ }^{8}$ Ahmad Fuadi, 223.

${ }^{9}$ Ahmad Fuadi, 400.

${ }^{10}$ Ahmad Fuadi, 402-403.
} 
angkatan 1988 dan bersekolah selama 5 tahun. Sebagaimana kutipan berikut: "Aku sekilas melihat sampulnya: Catatan Perilaku Angkatan 1988. ${ }^{11}$ Latar Sosial: latar sosial dalam novel Negeri 5 Menara ini adalah selama 6 tahun menjalani kehidupan di Pondok Madani selama 24 jam. Saling tolong menolong sesama dan banyak rasa kekeluargaan yang diciptakan dalam novel ini.

6) Amanat

Amanat dari Novel Negeri 5 Menara ini adalah kembali ke sinopsis yaitu "mantera" sakti Man jadda wajada. Siapa yang bersungguh-sungguh pasti sukses.

\section{d. Nilai-nilai Karakter Dalam Novel Negeri 5 Menara}

Dari hasil penelitian novel Negeri 5 Menara bahwa nilai-nilai yang akan peneliti bahas dan nilai-nilai yang terkandung dalam novel negeri 5 menara ini adalah : Religius, Disiplin, Kerja Keras, Peduli Sosial, Cinta Tanah Air, Mandiri.

e. Penerapan Nilai Karakter Dalam Novel Negeri 5 Menara Pada Siswa Kelas XII Usaha Perjalanan Wisata 2 di SMK Satya Widya Surabaya

Nilai-nilai karakter yang ada dalam novel Negeri 5 Menara itu sudah diterapkan pada siswa-siswa di SMK Satya Widya dalam kegiatan sehari-hari. Keterangan ini didapat dari hasil wawancara dengan Kepala Program Pariwisata SMK Satya Widya Surabaya, yang mana dalam isi wawancara tersebut dirinya mengatakan bahwa pendidikan karakter atau penerapan karakter sangat penting dilaksanakan di sekolah itu karena pendidikan karakter dapat membentuk sifat dan sikap siswa. Dan menurutnya penerapan nilai-nilai karakter di sekolah ini sudah sesuai harapan contohnya tidak ada kasus yang buruk yang terjadi sampai melibatkan siswa. Itu menjadi bukti bahwa siswa mampu dan sudah menerapkan nilai-nilai karakter yang diberikan guru. Dan tuturnya lagi beliau mempunyai harapan kedepan terkait penerapan nilai-nilai karakter yaitu harapannya adalah setelah lulus dari sekolah siswa tetap mempunyai sifat atau sikap yang teladan seperti yang mereka pelajari baik dirumah, lingkungan sekolah, lingkungan pergaulan. Jadi bagusnya karakter itu lebih bagus dibentuk dari rumah atau keluarga. Karena karakter pertama terbentuk dari keluarga. ${ }^{12}$

Peneliti juga melakukan wawancara dengan salah satu guru Pendidikan Agama Islam yang mana karena peneliti belajar di jurusan Pendidikan Agama Islam maka peneliti melakukan wawancara dengan salah satu guru PAI yang ada disana sehingga

\footnotetext{
${ }^{11}$ Ahmad Fuadi, 315.

${ }^{12}$ Rahindriati, Wawancara, Surabaya, 19 Februari 2019.
} 
peneliti mendapat gambaran bagaimana penerapan nilai-nilai karakter di sekolah dalam segi pandangan guru mata pelajaran Pendidikan Agama Islam.

Dari hasil wawancara peneliti dengan guru PAI beliau mengatakan bahwa penerapan nilai karakter di sekolah ini sudah ditanamkan oleh guru pada siswanya. Contohnya nilai Religius menanamkan kekuatan iman, melakukan kewajiban ibadah, menghindari larangan-larangan agama secara umum tanggung jawab pada diri sendiri, Orang Tua, Allah. Intinya menghormati Orang Tua lalu pengamalan sholat dhuha bergilir dan mengaji setiap memulai pelajaran. Yang kedua nilai Disiplin menyangkut dalam waktu ketika belajar, konsekuensinya jika anak-anak melanggar harus membuat sanksi, suruh membuat janji atau ikrar untuk tidak mengulang, membersihkan kelas, masuk perpustakaan, keluar kelas, membuat rangkuman yang disampaikan saat itu, menulis Al-Qur'an dan terjemahnya meskipun tidak rutin. Yang ketiga nilai Kerja Keras yang ditanamkan adalah memberi motivasi bahwa sebagai Islam tidak cukup sebagai ibadah mahdhoh tetapi juga mengaplikasikan nilai-nilai ibadahnya dalam kehidupan sehari-hari.

Dalam hal ini, misal pelajaran Qur'an surat Al-Jumuah yaitu setelah selesai solat jum'at tidak dianjurkan duduk-duduk di masjid, mengaplikasikan beberapa kisah tentang semangatnya Rasulullah SAW dan sahabat untuk mencari penghidupan, berdagang dan lain-lain. Yang keempat nilai Peduli Sosial disampaikan dalam mengajarkan materi materi tentang Ukhuwah Islamiyah dan Ta'awun 'alal birri wa taqwa, Ukhuwah Nasraniyah, hormat menghormati sesama manusia berbeda agama, materi tentang (toleransi beragama). Yang kelima nilai Cinta Tanah Air disampaikan dalam mengajarkan materi Hubbul Wathoni yaitu dengan penyampaian ketika anakanak mempelajari tentang perkembangan Islam di Indonesia disitu dikasih nilai-nilai Cinta Tanah Air, mengamalkan keislaman dengan budaya keseharian Indonesia mulai dari cara berpakaian Islami ala Indonesia atau menyampaikan salam ala Indonesia. Yang terakhir keenam adalah nilai Mandiri yang ditanamkan yaitu adalah tidak menggantungkan hidup dengan orang tua. Harus berusaha mengerjakan apapun sendiri sehingga siswa akan terdidik untuk mandiri. ${ }^{13}$

\footnotetext{
${ }^{13}$ Muhammad Ghufron, Wawancara, Surabaya, 22 Februari 2019.
} 


\section{Anasis Penelitian}

a. Religius

Penghambat: di sekolah satya widya ini ada 2 sesi yaitu pagi dan siang. Lalu penghambat yang lain juga sholat wajib dijadikan alasan untuk tidak mengikuti jam pelajaran, jadi guru menjadi bingung mau melarang tetapi mereka melaksanakan karena mereka izin untuk sholat wajib tetapi guru tidak tahu mereka melaksanakannya tidak. Penghambat yang lainnya juga karena sekolah ini sekolah umum maka terkadang ada masalah dengan agama Islam dan Non Islam. Penunjang: Visi antara lembaga dan pemerintah, lembaga dengan kurikulum, menjadi faktor pendorong penerapan religius, tetapi dari intern mayoritas untuk guru-guru sendiri untuk masalah agama mempunyai perhatian lebih jadi untuk menanamkan nilai religius setiap guru mata pelajaran pun mampu. Dan masyarakat sekitar juga sangat membantu dalam hal ini.

\section{b. Disiplin}

Penghambat: karena sekolah ini punya 2 sesi yaitu pagi dan siang, akhirnya kalau pagi banyak yang terlambat, begitu juga dengan siang. Lalu penghambat yang lain karena sekolah ini kejuruan jadi mata pelajaran mereka banyak yang condong ke keterampilan jadi banyak praktek ke laboratorium pariwisata dan hotel jadi terkesan siswa banyak keluar di jam pelajaran dan terkesan tidak disiplin. Penunjang: harus ada jadwal yang ketat untuk mata pelajaran dan aktivitas lain yaitu jadwal jam masuk, pulang dan lain-lain. Penunjang lainnya adalah adanya tim khusus untuk ketertiban di sekolah, orang tua dan pemerintah. Lalu adanya satpol PP juga membantu dalam razia siswa yang berada diluar sekolah saat jam pelajaran sekolah.

c. Kerja Keras

Penghambat: Jaman di era sekarang ini menjadi penghambat dalam kerja keras akhirnya minat kerja keras menurun karena fasilitas teknologi yang membuat mereka nyaman. Karena dengan adanya teknologi membuat siswa tidak mau repot-repot. Penunjang: perlu adanya penekanan kepada siswa dan menanamkan visi kepada mereka bahwa tidak boleh atau tidak bisa menggantungkan sesuatu pada siapapun, memang perlu jaringan tetapi dari diri sendiri dulu untuk menanamkan kerja keras terlebih dahulu, jangan memanjakan sesuatu karena adanya teknologi.

d. Peduli Sosial

Penghambat: nilai peduli sosial pada siswa sebenarnya bagus tetapi harus penuh arahan, karena anak zaman sekarang nilai peduli sosialnya tinggi tapi jadi berlanjut ke 
negatif. Penunjang: fasilitas yang dimiliki sekolah untuk peduli lingkungannya, adanya aktivitas-aktivitas kegiatan yang mendukung.

e. Cinta Tanah Air

Penghambat: Kurang kepekaan terhadap diri mereka tentang nilai cinta tanah air ini, kalau ada konflik atau hal-hal menyentuh yang terjadi mereka baru berontak. Penunjang: terus digali dan ditanamkan rasa cinta tanah air ini untuk melihat daerahdaerah yang membuat mereka cinta tanah air.

f. Mandiri

Penghambat: banyak dari siswa karena sudah menjadi kebiasaan di rumah hidup terlalu enak, dan semakin meningkatnya teknologi pada zaman sekarang ini menjadikan anak malas dan bergantung pada semua itu. Penunjang: memperbanyak memberi nasihat kalau hidup tidak harus menggantungkan pada orang lain. Karena hasil sendiri lebih memuaskan, dan selama bisa diatasi sendiri maka tidak perlu menunggu bantuan orang lain.

\section{Kesimpulan dan Rekomendasi}

1. Kesimpulan

Bahwa nilai-nilai karakter yang terdapat dalam novel negeri 5 menara adalah mencakup Religius, Disiplin, Kerja Keras, Peduli Sosial, Cinta Tanah Air, Mandiri. Nilai-nilai yang sudah diterapkan pada siswa kelas XII Usaha Perjalanan Wisata 2 di SMK Satya Widya adalah Pertama Religius yaitu pengamalan sholat dhuha bergilir dan membaca doa sebelum pelajaran dimulai, Kedua Disiplin yaitu pemberian hukuman kepada siswa yang terlambat dengan cara lari keliling lapangan sekolah, Ketiga Kerja Keras yaitu menciptakan suasana belajar yang memacu daya tahan kerja seperti memberi tugas dan diberi batas waktu untuk pengumpulannya. Keempat Cinta Tanah Air yaitu berkunjung ke museum Mpu Tantular. Kelima Peduli Sosial yaitu setiap ada wali murid yang meninggal, pihak sekolah dan para siswa lainnya bergegas mengumpulkan uang untuk disumbangkan kepada yang bersangkutan. Keenam Mandiri yaitu mandiri dalam melakukan kewajibannya seperti piket kelas, mandiri dalam bidang pelajaran maksudnya adalah yakin bahwa akan meraih nilai tinggi. Faktor penghambat dan penunjang dalam penerapan nilai-nilai karakter disini adalah pertama penghambatnya adalah karena di sekolah ini ada 2 sesi yaitu sekolah pagi dan siang sehingga penerapan nilai karakter ini terhambat. Dan untuk penunjangnya dari 
segi fasilitas sangat dan keakraban serta kekompakan antar guru sangat mendukung dan bisa memfasilitasi dalam penerapan nilai-nilai karakter di sekolah ini.

2. Rekomendasi

Penerapan kebijakan disekolah, kurang didukung sumber daya manusia yang ada sehingga untuk menerapkan butuh kekompakan dan komimen bersama dalam mengembangkan kerekerisik siswa sehingga bisa memperoleh hasil yang maksimal. Orang tua harus di libatkat dalam program-program yang dimiliki sekolah.

\section{Referensi}

Ahmad Fuadi. 2009. Negeri 5 Menara. Jakarta: Gramedia Pustaka Utama

Daryanto dan Suryatri Darmiatun. 2013. Implementasi Pendidikan Karakter di Sekolah. Yogyakarta: Gava Media

Muhammad Ghufron, Wawancara Dengan Kepala Sekolah, Surabaya, 22 Februari 2020.

Rahindriati, Wawancara Dengan Wak Kurikulum, Surabaya, 19 Februari 2020.

Sutarjo Adisusilo, Pembelajaran Nilai Karakter (Konstruktivisme dan VCT Sebagai Inovasi Pendekatan Pembelajaran Afektif), (Jakarta: Raja Gafindo Persada, 2012)

Musfah. 2011. Pendidikan Karakter: Sebuah Tawaran Model Pendidikan HolistikIntegralistik. Jakarta: Prenada Media 